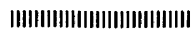

論 文

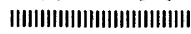

\title{
レオノフモデルを用いた非定常粘弾性流れの有限要素解析
}

（第 2 報）二次元急絞り流路におけるスタートアップ流れの応力場

$\begin{array}{llll}\text { 大阪大学工学部 } & \text { 中 } & \text { 村 } & \text { 喜 代 次 (会員) } \\ \text { 大阪大学工学部 } & \text { 山 } & \text { 本 } & \text { 剛 宏 (会員) }\end{array}$

\section{Finite Element Simulation of Unsteady Viscoelastic Flow Using Leonov Model}

\author{
Part 2 : Stress Field of Two-Dimensional Start-Up. Flow \\ through Abrupt Contraction
}

\author{
Kiyoji Nakamura and Takehiro Yamamoto \\ Department of Mechanical Engeneering, Osaka University, Suita, Osaka
}

\begin{abstract}
Unsteady viscoelastic flows were studied using the finite element method. The Leonov model has been used to represent the rheological behavior of the viscoelastic fluid. We numerically analyzed a start-up flow problem in channels with 4:1 and 8:3 abrupt contraction for polystyrene (STYRON 678) at $190^{\circ} \mathrm{C}$, and obtained the predictions of transient behavior of velocity and stress fields. In the part 1 , the results of velocity field were reported and in the present paper, the results of stress as field are reported.

The results obtained from the simulation are follows, (1) normal stress difference along the center line takes the maximum value just upstream the contraction, and (2) size of vortices increase to restrain the growth of velocity gradient and to relax the growth of normal stress difference.
\end{abstract}

(Received August 27, 1993)

(Accepted for Publication June 3, 1994)

\section{摘要}

目的 構成式に Leonov モデルを使用し, 粘弾性流体の二次元急絞り流路におけるスタートアップ流れの数值解析を行うこ とにより，粘弾性流体の非定常流動特性を調べる. 第 1 報では速度場の結果を報告した. 第 2 報では応力場の解析結果を示す.

成果 有限要素法を用いて粘弾性流体のスタートアップ流れの数值計算を行い，つぎの結果を得た。

（1）中心線上の法線応力差は絞り部の少し上流側で最大值をとる.

(2) 流路角部に渦が発生する. そして，その渦が大きくなることによって，絞り部付近の速度勾配の增大が抑えられ，それに よって法線応力差の増大が緩和されることが分かった。 つまり渦が stress relief mechanism として働くことが確認された。

(平成 5 年 8 月 27 日受理) (平成 6 年 6 月 3 日審査終了)

\section{1. 緒 言}

現在までに行われている粘弾性流れの数値解析の 大部分は定常流れを対象としたものであり, 非定常 流れを対象としたものは少ない. しかし, 粘弾性流 体はその時間依存特性のために, 非定常流れにおい
てニュートン流体にはみられない複雑な挙動)を示 す.さらに非定常流れは高分子成形加工のように工 業的にあよくみられる流れである. 従って粘弾性流 体の非定常流れについて数值解析を行い, その非定 常特性を調べることは興味深い問題である.

本研究では非定常流れとしてスタートアップ流れ 
を取り上げた。これまでに急絞り流路におけるス夕 ートアップ流れのような複雑な流れについては実験 による研究 ${ }^{23}$ は行われているが, 数值解析はほとん ど行われていない，そこで, 本研究では急絞り流路 におけるスタートアップ流れの数值解析を行い，そ の結果をもとに粘弾性流体の非定常特性について考 察する. また粘弾性流体の特性を記述する構成式と して, 高分子融液に対して提案された Leonov モデ ル4.5)を使用する.

第 1 報(6)では流速場について数值解析を行い, 流 速のオーバーシュートや渦の大きさの時間的変化を 数值計算によって予測した．第 2 報では応力場にっ いて数値解析を行い，その結果と第 1 報で示した流 速場の解析結果とを比較しながら，粘弾性流体の非 定常特性について考察する.

\section{2. 基礎方程式}

本研究では 2 次元非定常流れを考える.さらに流 れは creeping flow であるとして, 運動方程式中の 慣性項を無視する．また流体は非圧縮性流体とす る.

以下に基礎方程式を示す，構成式には Leonov モ デルを用いる.

連続の式：

$\nabla \cdot \boldsymbol{V}=0$

Cauchy の運動方程式：

$$
\begin{aligned}
& \rho \frac{\partial \boldsymbol{V}}{\partial t}-\rho \frac{\partial \boldsymbol{V}}{\partial t} p \nabla \cdot \boldsymbol{\sigma}=\mathbf{0} \\
& \boldsymbol{\sigma}=-p \mathbf{I}+\boldsymbol{\tau}
\end{aligned}
$$

ここで, $V$ は速度べクトル, $\rho$ は流体の密度, $\tau$ は偏 差応力テンソル, I は単位テンソル, $p$ は圧力であ る. 『はナブラ演算子を表す。

$$
\begin{aligned}
& \text { 構成式 (Leonov モデル): } \\
& \boldsymbol{\tau}=2 \boldsymbol{\eta}_{0} s \mathbf{D}+\sum_{k=1}^{N} \boldsymbol{\mu}_{k} \mathbf{C}^{k} \\
& \stackrel{\nabla}{\mathbf{C}^{k}}+\frac{1}{2 \boldsymbol{\theta}_{k}}\left(\mathbf{C}^{k} \cdot \mathbf{C}^{k}-\mathbf{I}\right)=\mathbf{0} \\
& \boldsymbol{\mu}_{k} \equiv \boldsymbol{\eta}_{k} / \boldsymbol{\theta}_{k} \\
& \boldsymbol{\eta}_{0} \equiv \sum_{k=1}^{N} \frac{\boldsymbol{\eta}_{k}}{1-\boldsymbol{s}} \\
& \mathbf{D}=\frac{1}{2}\left(\nabla \boldsymbol{V}+\nabla \boldsymbol{V}^{\mathrm{T}}\right) \\
& \stackrel{\nabla}{\mathbf{C}}^{k} \equiv \frac{\partial \mathbf{C}^{k}}{\boldsymbol{\partial} t}+\boldsymbol{V} \cdot \nabla \mathbf{C}^{k}-\nabla \boldsymbol{V}^{\mathrm{T}} \bullet \mathbf{C}^{k}-\mathbf{C}^{k} \bullet \nabla \boldsymbol{V} \\
& \operatorname{det} \mathbf{C}^{k}=1
\end{aligned}
$$

ここで, $\eta_{k}, \boldsymbol{\theta}_{k}, s$ は Leonov モデルのパラメータで それぞれ第 $k$ モードの粘度，第 $k$ モードの緩和時
間，レオロジ定数である． $N$ はモード数である． $\mathbf{C}^{k}$ は第 $k$ モードの Finger ひずみテンソル， $\mathbf{D}$ は変形 速度テンソルを表す. [・]

\section{3. 数值計算スキーム}

数値計算スキームは第 1 報で示したものと同じで ある，以下にそのスキームを簡単に示す。

空間に関しては有限要素法を用いた離散化を行 う。速度とひずみに対しては 6 節点三角形要素を, 圧力に対しては 3 節点三角形要素を使用する．時間 に関する離散化は速度一圧力系には Crank-Nicolson 法を,ひずみ系にはEuler の前進差分を用い る.そして以上の方法で離散化した式を各時間ステ ップについて解くことによって非定常解を得る.

スタートアップ流れのモデルとして次のような流 れを考える. 流体は初期状態で静止している. そし

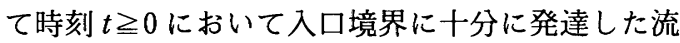
れの境界值を与える，入口境界で与える十分に発達 した流れの流速分布は Upadhyay ら”の方法に基づ いて計算する.

また計算コストの低減のために非常に小さな緩和 時間を持つモードに対しては quick adaptation近 似帛を適用する。

\section{4. 数値解析}

\section{1 計算条件}

本解析では試料流体として $190^{\circ} \mathrm{C}$ の゚リスチレン 融夜（STYRON 678, Dow Chemical) を考えた。こ の流体はせん断粘度の shear-thinning 性と伸長粘 度の stretch-thickening 性を示す. Leonov モデル のパラメータ9（表 1）は第 1 報で使用したものと同 じである. 第 2 モードに対して quick adaptation 近似を用いる.

解析は絞り比が $4: 1$ と $8: 3$ の 2 種類の急絞り流 路について行った. 流路形状, 境界条件, 使用した 有限要素メッシュ（図 1), 計算条件 (入口平均流速 $\bar{u}_{\mathrm{ent}}$ ，出口平均流速 $\bar{u}_{\mathrm{ext}}$; 表 2） は第 1 報のものと同 じである．以下の文章で（A)，(B) はそれぞれ表 2 の条件に対応する，また，表 2 に示した流速は本計 算のほぼ上限に相当する.

\section{2 計算結果}

図 2 , 図 3 に $t=1.0 \mathrm{~s}$ における法線応力差 $\tau_{x x}-\tau_{y y}$ およびせん断応力 $\left|\tau_{x y}\right|$ の分布を示す. 図 4 に $\tau_{x x}-\tau_{y y}$ 
Table 1 Parameters for Leonov Model (STYRON 678 at $190^{\circ} \mathrm{C}$ )

\begin{tabular}{|c|c|c|}
\hline $\mathrm{s}[-]$ & $\eta_{k}[\mathrm{~Pa} \cdot \mathrm{s}]$ & $\theta_{k}[\mathrm{~s}]$ \\
\hline $9.0 \times 10^{-2}$ & $5.44 \times 10^{3}$ & 0.80 \\
& $1.50 \times 10^{3}$ & 0.027 \\
\hline
\end{tabular}

Table 2 Condition of Calculation

\begin{tabular}{|l|c|c|c|}
\hline & contraction ratio & $\bar{u}_{\text {ent }}[\mathrm{mm} / \mathrm{s}]$ & $\bar{u}_{\text {ext }}[\mathrm{mm} / \mathrm{s}]$ \\
\hline (A) & $4: 1$ & 3.0 & 12.0 \\
\hline (B) & $8: 3$ & 4.5 & 12.0 \\
\hline
\end{tabular}

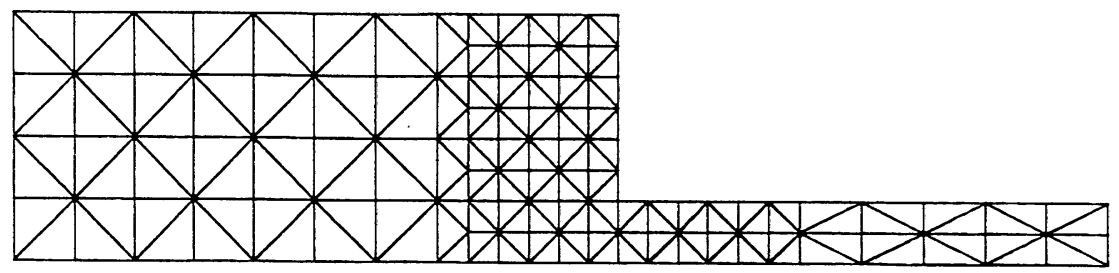

( a )

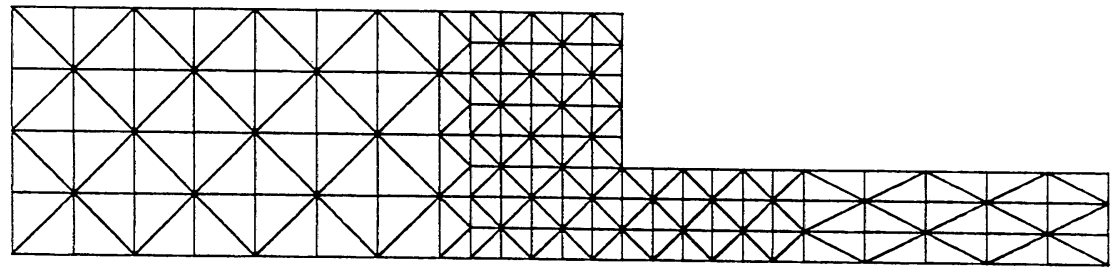

( b )

Fig. 1 Finite Element Meshes Used for the Numerical Simulation : (a) Two Dimensional Channel with $4: 1$ Abrupt Contraction (MESH 1), 192 Elements and 445 Nodes. (b) Two Dimensional Channel with $8: 3$ Abrupt Contraction (MESH 2), 214 Elements and 489 Nodes

の時間変化を, 困 5 に $\left|\tau_{x y}\right|$ の時間変化を示す. $\tau_{x x}-\tau_{y y}$ について次のような特徴がみられる。

（i）流路の中心付近では絞りの上流側から大き くなり，絞り部を通過すると小さくなる.

(ii ) 絞り部の下流側では壁面に近いほど大きい.

（i）は流れ場の伸長特性によるもので，（ii）は せん断特性によるものである，絞り付近では絞りの 影響により, 流れ方向の速度勾配の増大によって伸 長速度が増大する。 それで，伸長粘度の stretchthickening 性によって伸長粘度が大きくなり，そ の結果として伸長応力が増大する，絞りの下流側で は流速が大きくなり，壁面におけるせん断速度も増 大する，そのために，単純せん断流れにおける第 1 法線応力差の増大に相当する現象が起きている.

$\left|\tau_{x y}\right|$ については次のような特徴がみられる.

（i ）渦の存在のために流路の凹角部では $\left|\tau_{x y}\right|$ は 小さい. (ii）絞り部の下流側で $\left|\tau_{x y}\right|$ は大きくなる.

（i）は渦領域で流速が非常に小さくなることが 原因である.（ii）は絞り部の後方では流速の増大と ともにせん断速度が増大し，その結果として $\left|\tau_{x y}\right|$ が 大きくなるからである.

応力は（A）と（B）のいずれの場合であ入口付近 と絞り部付近から発達することが分かる，また，応 力の值は絞り比の大きい（A）の方が大きくなる傾 向がある.しかし絞りから十分に離れた下流側では せん断特性が支配的であり，本計算では $\bar{u}_{\mathrm{ext}}$ が等し いために，(A）と（B）で $\tau_{x x}-\tau_{y y} や\left|\tau_{x y}\right|$ にあまり違 いはみられない，一方，伸長特性が支配的な絞り部 付近では $\tau_{x x}-\tau_{y y}$ に違いがみられる. $\tau_{x x}-\tau_{y y}$ は絞り 比が大きく伸長効果が強くなる（A）の方が大きく なっている.

次に示す速度勾配と法線応力差の計算加ら，第 1 報で報告した渦の大きさの時間変化は絞り部付近の 
( a )
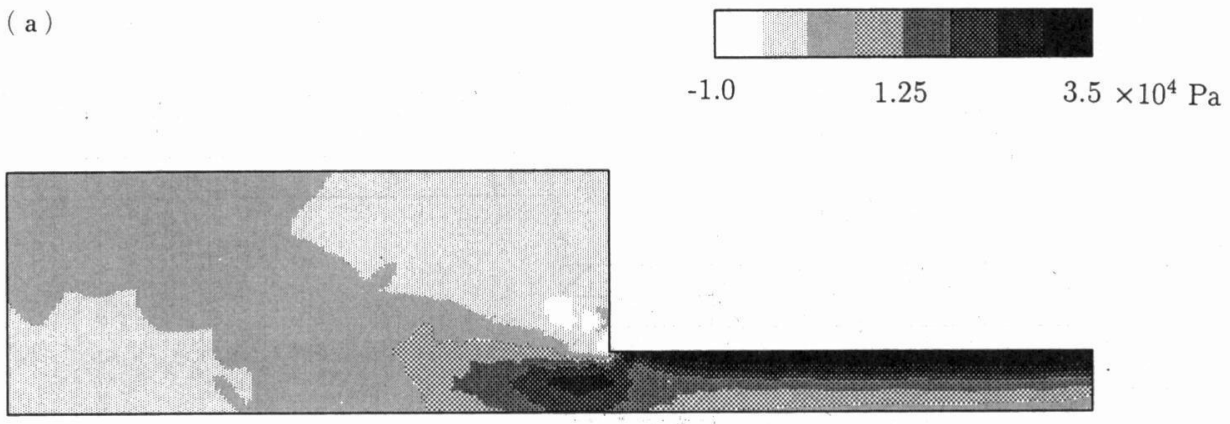

( b )
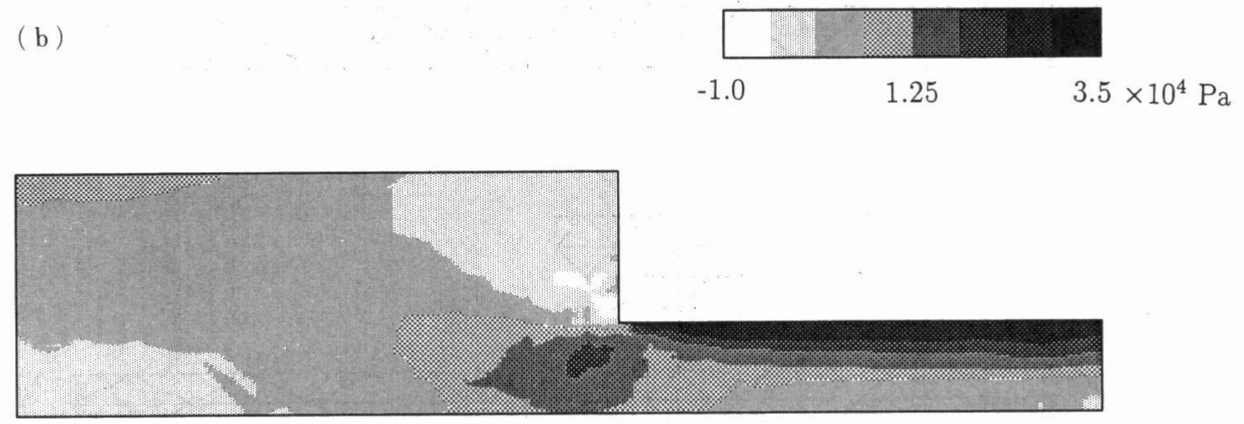

Fig. 2 Distribution of $\tau_{x x}-\tau_{y y}$ at $1.0 \mathrm{~s}$; (a) MESH 1, $\bar{u}_{\text {ent }}=3.0 \mathrm{~mm} / \mathrm{s}$, (b) $\mathrm{MESH} 2, \bar{u}_{\text {ent }}=4.5 \mathrm{~mm} / \mathrm{s}$
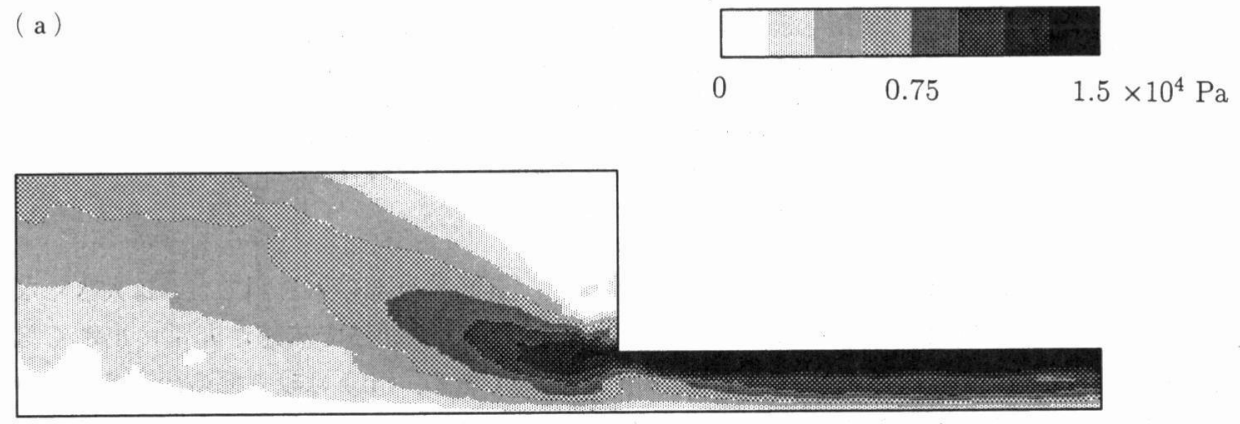

( b )
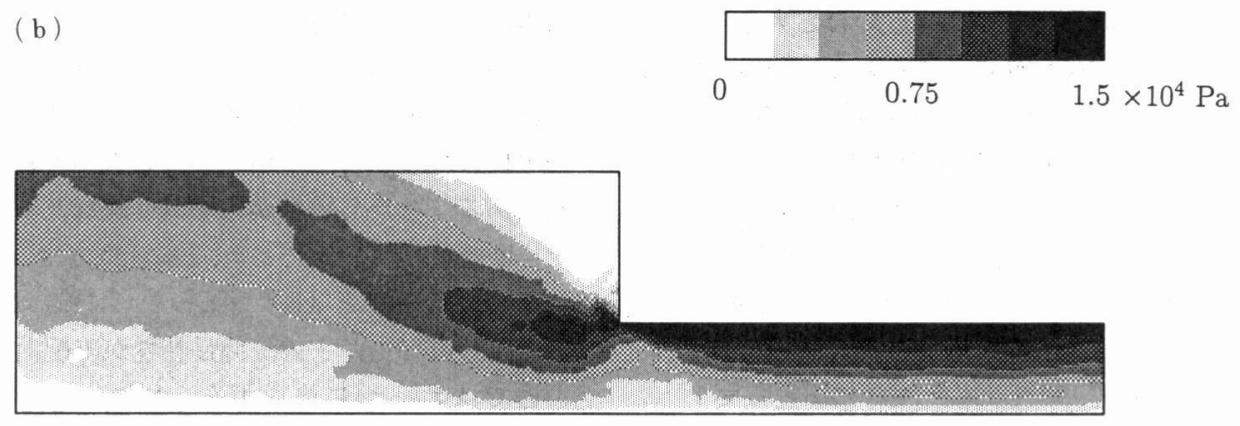

Fig. 3 Distribution of $\left|\tau_{x y}\right|$ at $1.0 \mathrm{~s}$; (a) MESH 1, $\bar{u}_{\text {ent }}$ $=3.0 \mathrm{~mm} / \mathrm{s}$, (b) $\mathrm{MESH} 2, \bar{u}_{\mathrm{ent}}=4.5 \mathrm{~mm} / \mathrm{s}$ 


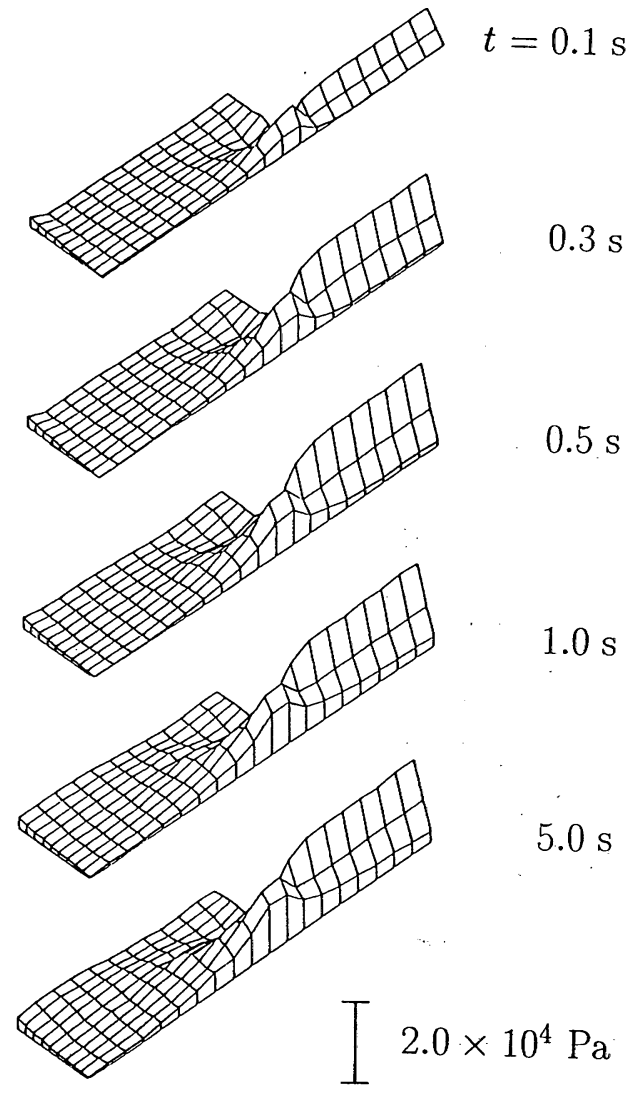

(a)

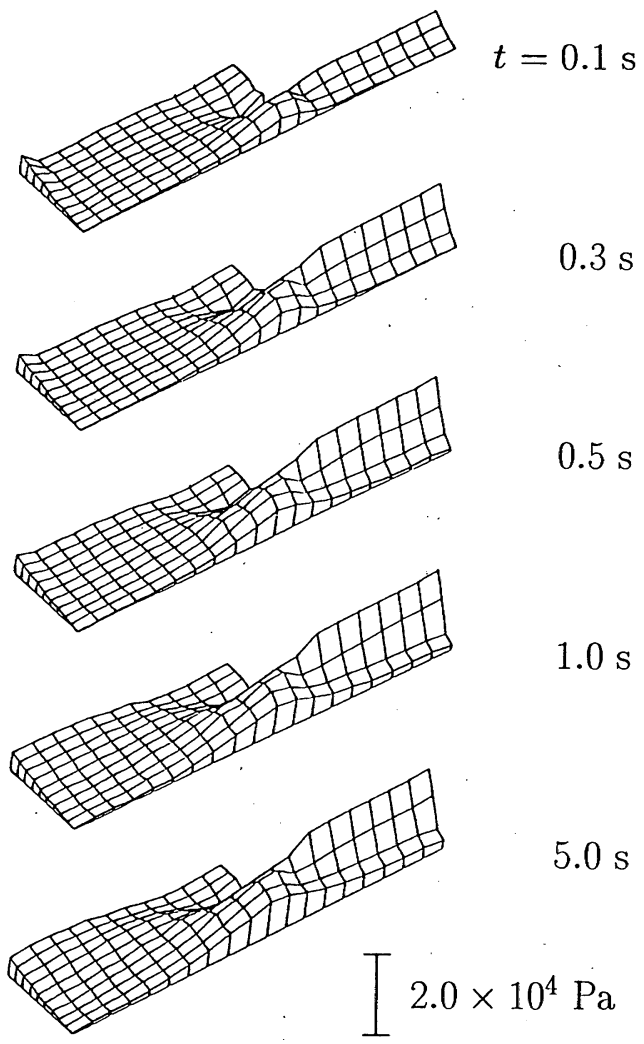

( b )

Fig. 4 Change of $\tau_{x x}-\tau_{y y}$ with Time ; (a) MESH 1, $\bar{u}_{\text {ent }}=3.0 \mathrm{~mm} / \mathrm{s}$, (b) MESH $2, \bar{u}_{\text {ent }}=4.5 \mathrm{~mm} / \mathrm{s}$

伸長特性と関係があることが分かった.

図 6 に中心線上の速度勾配 $\partial u / \partial x$ の分布を示す. ニュートン流体の物性值は粘度がポリスチレン融液 の零せん断粘度 $\eta_{0}$ に等しく, 密度もポリスチレン融 液のあのと等しくなるように設定した。ここでニュ 一トン流体の計算結果は定常状態における值であ る. ニュートン流体の場合には定常值に達するまで の時間が非常に短く, 流動開始直後の值と変わらな い. ポリスチレン融液の場合, $\partial u / \partial x$ は流動の初期 には大きな值をとるが時間とともに小さくなる. そ して, 絞り部の少し上流側で最大值をとっている. また（A）と（B）のいずれの場合む二ュートン流 体の $\partial u / \partial x$ より小さな值をとる.これは粘弾性流体 の流れ場がニュートン流体の流れ場に比べて, 伸長 応力の増大を抑えるような形状をとっているためで ある. また, 絞り比が大きい（A）の方が中心線上の $\partial u / \partial x$ が大きくなる。

図 7 に中心線上の $\tau_{x x}-\tau_{y y}\left[=4 \eta_{0} s \partial u \partial x+\sum_{k=1}^{N} \mu_{k}\right.$
$\left.\left(C_{x x}^{k}-C_{y y}^{k}\right)\right]$ の分布を示す. いずれの場合む $\tau_{x x}-\tau_{y y}$ は絞り部の近くで大きな值をとっており，絞り部の 少し上流で最大值を示すことが分かる。これは絞り 部の近くで伸長応力が大きくなっていることを示し ている.この領域は $\partial u^{\prime} \partial x$ が大きくなることからも 伸長特性が支配的であることが分かる.

また図 6,7 の結果において解の振動がみられる が，これはメッシュの粗分割によるものである.

図 8 に渦の大きさの時間変化を示す. 渦の大きさ はいったん大きくなり, 最大值をとったあと減少し 一定值に落ちうく. 図 7 と比較すると, 渦の成長に よって $\tau_{x x}-\tau_{y y}$ の増大の原因の一つである $\partial u / \partial x$ が 抑えられていることが分かる。

次に図 9 に絞り部とその上流および下流側 3.5 $\mathrm{mm}$ における中心線上の $\tau_{x x}-\tau_{y y}$ の時間変化を示す. 定量的には違いがあるが, 定性的な傾向はいずれの 場合あ同じである. 流動の初期において $\tau_{x x}-\tau_{y y}$ は 急激に増大し, $t=1.0 \mathrm{~s}$ 付近でその変化は小さくな 


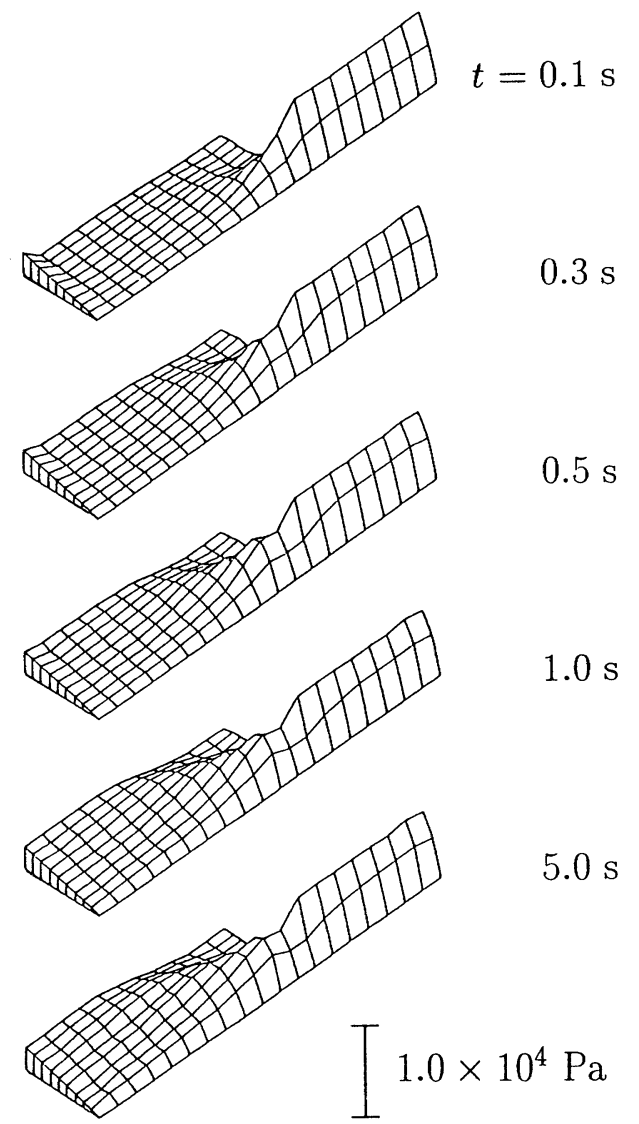

( a )

Fig. 5 Change of $\left|\tau_{x y}\right|$ with Time; (a) MESH 1, $\bar{u}_{\text {ent }}$

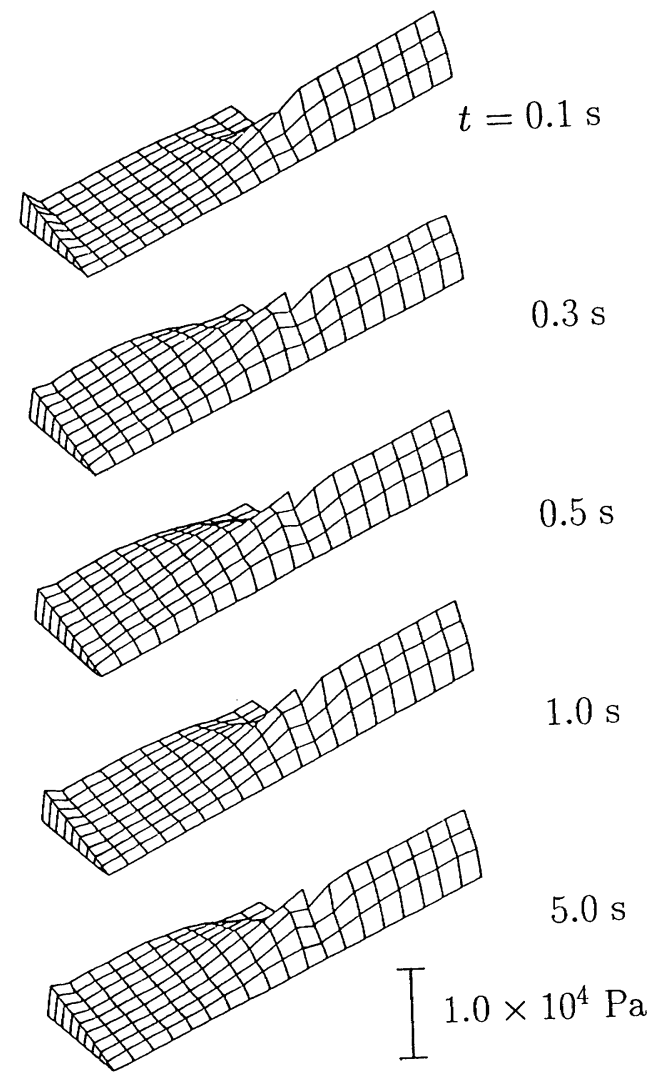

( b )

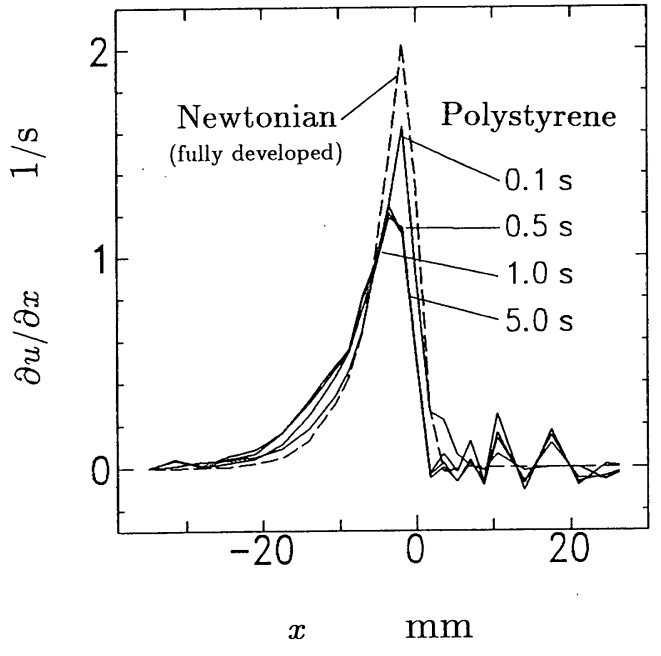

( a )

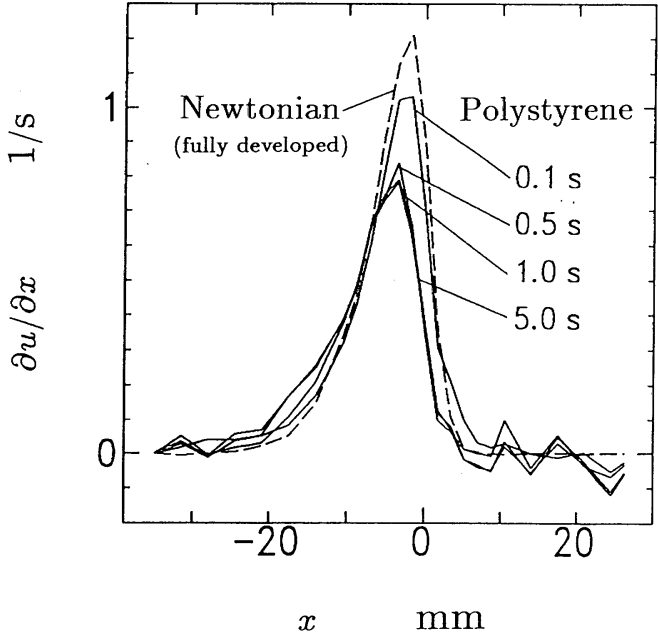

( b )

Fig. 6 Change of Velocity Gradient $\partial u / \partial x$ with Time on the Center Line ; (a) MESH $1, \bar{u}_{\text {ent }}=3.0 \mathrm{~mm} / \mathrm{s}$, (b) MESH $2, \bar{u}_{\text {ent }}=4.5 \mathrm{~mm} / \mathrm{s}$ 


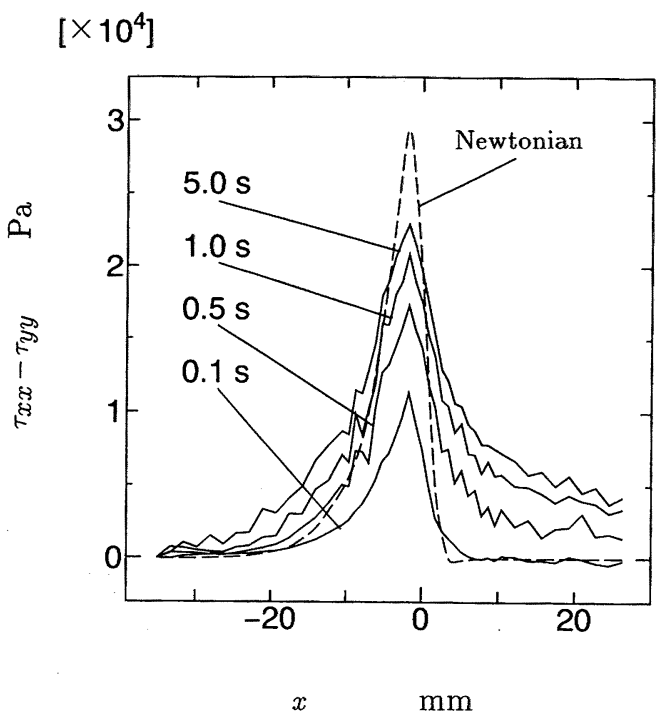

(a)

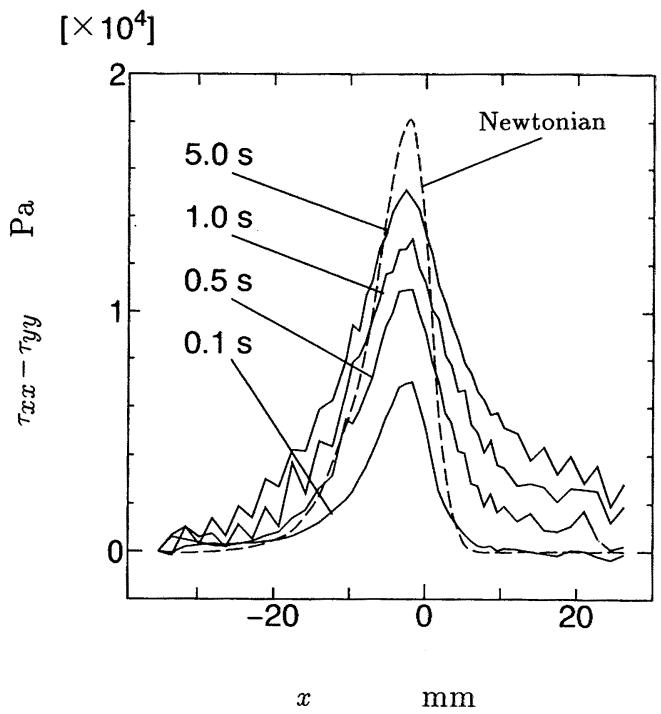

(b)

Fig. $7 \tau_{x x}-\tau_{y y}$ along the Center Line ; (a) MESH 1, $\bar{u}_{\text {ent }}=3.0 \mathrm{~mm} / \mathrm{s}$, (b) MESH $2, \bar{u}_{\text {ent }}=4.5 \mathrm{~mm} / \mathrm{s}$

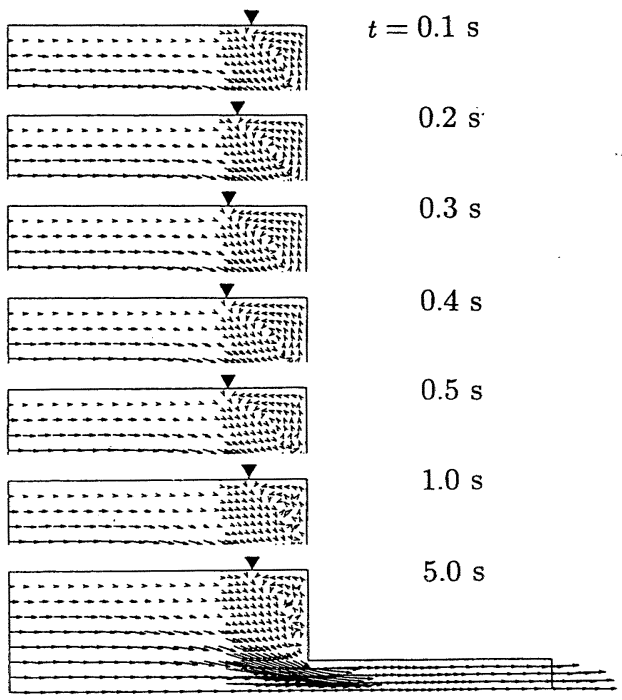

( a )

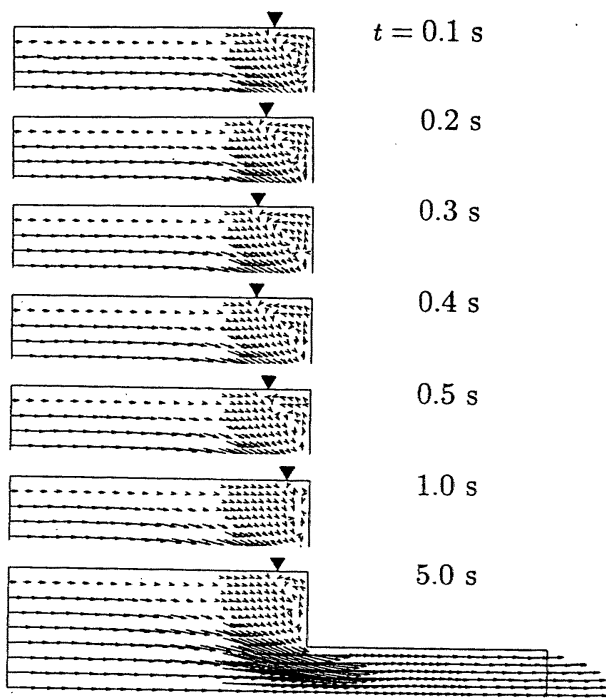

( b )

Fig. 8 Size of Corner Vortex ; (a) MESH 1, $\bar{u}_{\text {ent }}=3.0$ $\mathrm{mm} / \mathrm{s}$, (b) MESH 2, $\bar{u}_{\text {ent }}=4.5 \mathrm{~mm} / \mathrm{s}$

る.しかし, $\tau_{x x}-\tau_{y y}$ のオーバーシュートはみられな い.

先に示した渦の大きさの時間変化，速度勾配 $\partial u$ / $\partial x$, 中心線上の法線応力差 $\tau_{x x}-\tau_{y y}$ の計算結果を総 合すると，スタートアップ流れにおいて次のような
現象が生じていると考えられる.

流動初期では $\tau_{x x}-\tau_{y y}$ の増大の原因となる $\partial u / \partial x$ は大きく， $\tau_{x x}-\tau_{y y}$ が急激に増大する．しかし渦が成 長することによって $\partial u / \partial x$ が抑えられ，それによっ $\tau \tau_{x x}-\tau_{y y}$ の増大（伸長応力の増大）が緩和する。 つ 


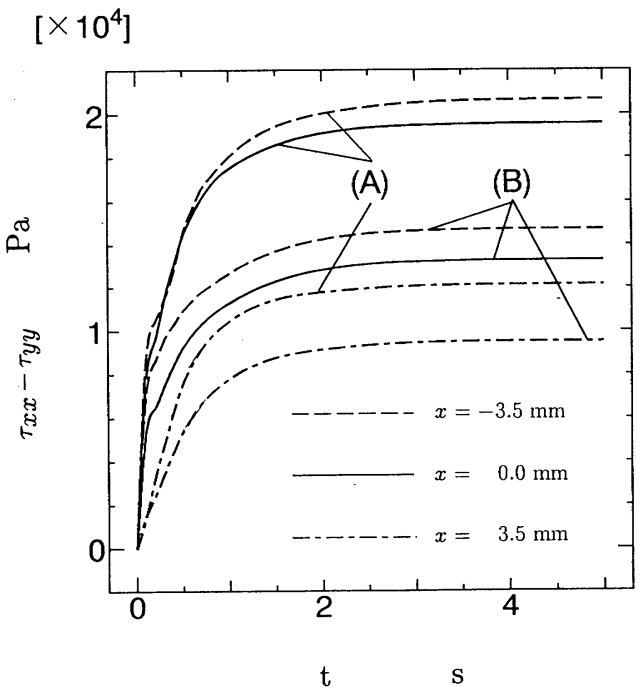

Fig. 9 Change of $\tau_{x x}-\tau_{y y}$ with Time on the Center Line

まり，循環二次流れは stress relief mechanism ${ }^{10)}$ として働いていると考えられる.

\section{5. 結 言}

本研究では急絞り流路におけるポリスチレン融液 （STYRON 678）の 2 次元スタートアップ流れの数 值計算を行った. 構成式として 2 モード Leonov モ デルを使用し，解析手法に有限要素法を用いた．第 2 報では応力場に関する解析を行った。 そして，そ の結果と第 1 報で報告した速度場に関する解析結果 から粘弾性流体の非定常特性にういて考察した.

スタートアップ流れのモデルとして, 初期状態で 流体は静止しているとして, $t \geqq 0$ において入口境界 で十分発達した流れを考えた。
数値解析から次の結果を得た。

（1）中心線上の法線応力差 $\tau_{x x}-\tau_{y y}$ は絞り部の少 し上流で最大值をとる. また, $\tau_{x x}-\tau_{y y}$ は流動初期に 急激に増大することが分かった。 しかし，オーバー シュートはみられなかった。

（2）流路角部の循環二次流れは絞り部付近におけ る流れの伸長特性に関係がある. 中心線上の速度勾 配 $\partial u / \partial x$ と $\tau_{x x}-\tau_{y y}$ を調べると, 流動初期は $\partial u / \partial x$ が大きく，そのために伸長応力が増大し， $\tau_{x x}-\tau_{y y}$ は 急激に増大する。これを抑えるために渦が大きくな り, $\partial u / \partial x$ が小さくなる. それで, $\tau_{x x}-\tau_{y y}$ の時間変 化む小さくなる，このように，循環二次流れは $\partial u /$ $\partial x$ を抑えることによって $\tau_{x x}-\tau_{y y}$ の増大を緩和して いる. つまり，循環二次流れが stress relief mechanism として働いていることが分かった. また，第 1 報で報告したように, 絞り比が $4: 1$ の流路の方が 8:3の流路より屯大きな渦が生じるのは, 絞り比の 大きい流路では $\partial u / \partial x$ が大きくなり, 伸長効果が強 くなるためである.

\section{参考文献}

1) R. I. Tanner; "Engineering Rheology", Clarendon Press (1985)

2) Y. Xu, P. Wang and R. Qian ; Rheol. Acta, 25, 239 (1986)

3）森教安, 海下巧, 中村喜代次; 日本レオロジー学会誌, 21, 33 (1993)

4) A. I. Leonov; Rheol. Acta, 15, 85 (1976)

5) A. I. Leonov, E. H. Lipkina, E. D. Paskhin and A. N. Prokunin; Rheol. Acta, 15, 411 (1976)

6）中村喜代次，山本剛宏; 蟣機誌， 47，T127（1994）

7) R. K. Upadhyay and A. I. Isayev; Rheol. Acta, 25, 80 (1986)

8) A. I. Leonov and A. N. Prokunin ; Rheol. Acta, 19, 393 (1980)

9) A. I. Isayev and C. A. Hieber; Rheol. Acta, 19, 168 (1980)

10) J. L. White and A. Kondo; J. Non-Newtonian Fluid Mech., 3, 41 (1978) 